\title{
Clinical, radiological and toxicity evaluation of Vestibular Schwannoma patients treated with Cyberknife ${ }^{\circledR}$ stereotactic radiosurgery-radiotherapy
}

\section{CyberKnife stereotaktik radyocerrahi- radyoterapi ile tedavi edilen Vestibuler Schwannoma hastalarının klinik, radyolojik ve toksisite açısından değerlendirilmesi}

\author{
Gonca Altınışık İnan ${ }^{1}$, Süheyla Aytaç Arslan², Ebru Karakaya ${ }^{3}$, Yıldız Güney ${ }^{4}$ \\ ${ }^{1}$ Ankara Atatürk Eğitim Ve Araştırma Hastanesi, Radyasyon Onkolojisi Kliniği, Ankara \\ ${ }^{2}$ Yıldırım Beyazıt Üniversitesi Tıp Fakültesi, Radyasyon Onkolojisi Bölümü \\ ${ }^{3}$ Ankara Abdurrahman Yurtaslan Onkoloji Eğitim Ve Araştırma Hastanesi, Radyasyon Onkolojisi Kliniğgi \\ ${ }^{4}$ Memorial Ankara Hastanesi, Rdyasyon Onkolojisi Kliniği
}

Dergiye Ulaşma Tarihi:28.05.2018 Dergiye Kabul Tarihi:05.11.2018 Doi: 10.5505/aot.2019.88700

\section{ÖZET}

GíRIŞ̧ ve AMAÇ: Bu çalışmada amaç CyberKnife stereotaktik radyocerrahi-radyoterapi uygulanan vestibuler schwannom hastalarının klinik, radyolojik ve toksisite verilerinin sunulmasıdır.

YÖNTEM ve GEREÇLER: Çalışma, Dr. Abdurrahman Yurtaslan Ankara Onkoloji Eğitim ve Araştırma Hastanesi Radyasyon Onkolojisi Kliniği'nde Haziran 2009 - Eylül 2014 tarihleri arasında vestibuler schwannom tanıs1 ile CyberKnife ${ }^{\circledR}$ (Accuray, Sunnyvale) cihazında stereotaktik radyocerrahi ve stereotaktik radyoterapi uygulanan hastaların klinik ve radyolojik değerlendirmeleri bununla birlikte tedavi öncesi ve son kontrollerine ait işitme değerlendirmesi (Gardner-Robertson skalası), 7. kranial sinir motor fonksiyon değerlendirmesi (HouseBrackmann skalası), 5. kranial sinir duyu muaynesi sonuçları ile toksisite değerlendirmesi yapılmıştır.

BULGULAR: Lokal kontrol, radyolojik stabil veya regresif hastalık olarak tanımlandı ve tüm hastaların son kontrollerinde \%100 olarak saptandı. GRS ve HB skoru tedavi öncesi değerleri tedavi sonrası değerlerinden istatistiksel olarak anlamlı farklı bulunmuştur $(p=0,042$ ve $p=0,046)$. Trigeminal toksisite $\% 7$ oranında saptanmıștır.

TARTIŞMA ve SONUÇ: Çalışmada lokal kontrol oranları literatür ile benzerlik göstermekle birlikte trigeminal toksisite oranı yüksek bulunmuştur. Doz ve fraksiyon şemalarının optimizasyonu için prospektif çalışmalara ihtiyaç duyulmaktadır.

Anahtar Kelimeler: Vestibuler schwannoma, Stereotaktik radyoterapi, Stereotaktik radyocerrahi, CyberKnife

\begin{abstract}
INTRODUCTION: The current study was done by means of clinical and radiological evaluations of vestibular schwannoma patients who treated with stereotactic radiosurgery or stereotactic radiotherapy using Cyberknife ${ }^{\circledR}$ (Accuray, Sunnywhale, USA).
\end{abstract}

MATERIAL and METHODS: Between June 2009 and September 2014,30 vestibular schwannoma patients were treated in Dr. AY. Ankara Oncology Training and Research Hospital, Department of Radiation Oncology. The patients were assessed before and after radiotherapy retrospectively, for hearing capacity (via GardnerRobertsonScale), motor function of cranial nerve 7. (via House-Brackmannscale), the sensorial function of cranial nerve 5.

RESULTS: Local control was defined as radiologically stable or regressive disease and achieved for all of the patients at the last control (\%100). Preradiotherapy mean values of GRS and HB scores were both statistically different from post radiotherapy mean values $(\mathrm{p}=0,042$ and $\mathrm{p}=0,046$, respectively). Trigeminal toxicity was determined as $7 \%$.

DISCUSSION AND CONCLUSION: When the study results were interpreted, while the local control results were found similar with the literature, trigeminal nerve toxicity values were higher than the reported results. Prospective studies are needed to optimize dose and fraction schedules.

Keywords: Vestibular schwannoma, Stereotactic radiosurgery, Stereotactic radiotherapy, Cyberknife.

\section{INTRODUCTION}

Vestibular schwannomas (VS) are benign tumours of Schwann cell origin that occur on the eighth cranial nerve. They are known also 
as acoustic neuromas and account for approximately $8 \%$ of all tumors inside the skull ${ }^{1}$. In recent years, an increasing incidence of diagnosed vestibular schwannoma has been reported by several centers ${ }^{2}$.The most common symptom is unilateral hearing loss by the tumor effect through either direct progressive injury to the cochlear nerve (slowly progressive sensorineural hearing loss) or interruption of cochlear blood supply (sudden and fluctuating hearing losses) ${ }^{3}$. Other commonlypresenting symptoms are tinnitus and balance disturbance, with it tumor progression can lead to brainstem compression, cranial neuropathies and hydrocephalus ${ }^{4}$. To management the VS include 4 strategies: observation, microsurgical resection, stereotactic radiosurgery (SRS) and fractionated stereotactic radiotherapy $(\mathrm{SRT})^{4,5}$.Tumor size, age, severity and duration of symptoms, the patient preference and the clinician experience are the factors for determaining which option should be undertaken for a particular case. There is no international consensus regarding the optimal treatment for vestibular schwannoma ${ }^{6}$.

Stereotactic radiation therapy is a type of external beam radiation therapy and can be delivered in two ways: 1. Stereotactic radiosurgery (SRS) delivers a single high dose of radiation to the tumour 2. Stereotactic radiotherapy (SRT) gives relatively smaller doses of radiation over a number of treatment sessions (called multiple,ex 1-5 fractions).Stereotactic radiosurgery was administered forVestibular schwannoma treatment using the Gamma Knife ${ }^{\circledR}$ by Leksell in $1969^{7}$,thenceforthstereotactic radiotherapy is increasingly used in the management of patients with vestibular schwannomas ${ }^{6}$. While many papers and review articles report satisfactory tumour growth control and few side effects with stereotactic radiosurgery/radiotherapy there is no consensus about which patient suitable for this treatment and RT parameters such as prescription dose, number of fractions etc.In this study we aimed to assess tumour control, hearing preservation status and complication rate after fractionated SRS/SRT by using CyberKnife ${ }^{\circledR}$ inpatientswith VS and to contribute the literature with the study results.

\section{PATIENTS and METHODS}

In the present study, we retrospectively reviewed 30 adult patients with 31 tumor sites, aged 18 years or older diagnosed as vestibuler schwannoma treated with SRS at Ankara Oncology Hospital Radiation Oncology Clinic between June 2009 and September 2014. Data was obtained from patients' medical charts and RT documents. Patients were included only if they had radiologic and/or pathologic confirmation and had their follow-up at our institution. Clinical assessment was done using with preRT and postRT Gardner Robertson Score (Table 1) for hearing evaluation and House-Brackman scale (Table 2) to quantify facial function. Tumour was assessed using Koos classification (Table 3) which is a common classification system frequently used for vestibular schwannoma ${ }^{8}$. Trigeminal nerve toxicity was also evaluated. Patients clinically assessed based on the presence or absence of: hypoesthesia, anesthesia and hyperesthesia. Patients had pre RT Response evaluation to treatment was done using gadolinum enhanced MRI and aforementioned tests.

\section{Radiation Therapy}

All the patients were immobilized in a fixed position with custom-made thermoplastic masks and simulated at computed tomography (CT) with a $1.5 \mathrm{~mm}$ slice thickness. These CT images were fused with the magnetic resonance imaging (MRI) images of the same slice thickness. Gross total volumes (GTVs) were delineated using contrast enhancement on T1-weighted series and an extra 1-mm margin was added to form planning target volume (PTV) depending on the discretion of treating physician.

Brainstem, chiasma, bilateral cochleas, internal acoustic canals, hypocampuses, eyes, lenses, optic nerves and healthy brain tissue outside the GTV were contoured as organs at risk. The contoured images were then sent to Cyberknife planning system and a prescribed dose of 11,25-22,50 Gy in 1-5 fractions were planned using sequential technic and applied with 6D skull tracking (figure 1).

\section{Statistics}

The collected data were evaluated using Statistical Package for Social Sciences (SPSS) for Windows 11.5. $\mathrm{p}=0.05$ was considered statistically significant. 


\section{RESULTS}

Total of 30 adults with 31 lesions treated at Ankara Oncology Hospital were reviewed. Patients demographics and clinical characteristics are presented in Table 4 . The median follow up was 21 (range, 2-57) months. Median age at diagnosis was 47 years ranging from 25 to 77 and male to female ratio was $14 / 16$ with a slightly female predominance. Prescribed dose was median 18 Gy (range, 10-22.5) with a median of 6 Gy (413) in median 3 (1-5) fractions. RT was delivered as a single fraction in 4 (13\%) patients and every other day in the rest of 10 (37\%). According to the Koos grading, the most predominant type was group $2(n=18$, $58 \%)$ and lesions were mostly right side located $(\mathrm{n}=19,63 \%)$.

Gadolinium enhanced MRI revealed a $64.5 \%$ partial response and $35.5 \%$ stable disease so an overall $100 \%$ local control achieved during a median 20 months (range, 257) follow-up.

When the plan data were evaluated median coverage, homogeneityindex (HI), conformityindex (CI), newconformityindex (nCI), andmonitor unit (MU) values were $\% 97,42 \quad(92,97-99,90), \% 87$ (71-95), 1,15 (1,05-1,41), 1,39 (1,1-2,33), 1,44 (1,13-2,33) ve 18405 (3276-36448) respectively.

Of the 30 patients, $11(35 \%)$ had nonservicable hearing before treatment and one of them progressed to servicable hearing after treatment. Four of nineteen patients with serviceable hearing worsened after RT (three patients had received 18 Gy / 3frc and remaining one had received $12.5 \mathrm{~Gy} / 1 \mathrm{frc}$ ) to nonservicable hearing. PostRT decreases in GRS was statistically significant $(\mathrm{p}=0,042)$. But the difference between pre and post RT GRS was not associated with cochlear dosimetry (1cc, max and mean and central).

Facial nerve assesment was done using pre and post RT House Berckman scoring. All patients except one (grade 4) had grade 1 facial nerve function before treatment. Scores worsened in 4 of 29 patients after RT and no change was seen in patient previously graded 4 , facial nerve toxicity rate was $13.3 \%$ and decrease in $\mathrm{HB}$ score was statistically significant $(\mathrm{p}=0.046)$.
Pre-treatment trigeminal assessment of the patients was done by grouping them as hypoesthesia, normal and hyperesthesia. Only one patient had sensory loss before treatment. The sensory loss in this case continued in the same way after the treatment. In addition, hypoesthesia was observed in 1 case, and hyperesthesia in 1 case was observed in 2 cases which pre-treatment trigeminal sensory function was normal. Based on these data, it was determined that the trigeminal toxicity ratio was $7 \%$.

Table 1: Gardner-Robertson Score

\begin{tabular}{|l|l|l|}
\hline & $\begin{array}{l}\text { pure tone } \\
\text { audiogram }(\mathrm{dB})\end{array}$ & $\begin{array}{l}\text { speech } \\
\text { discrimination } \\
(\%)\end{array}$ \\
\hline $\begin{array}{l}\text { Grade I (good- } \\
\text { excellent) }\end{array}$ & $0-30$ & $70-100$ \\
\hline $\begin{array}{l}\text { Grade II } \\
\text { (serviceable) }\end{array}$ & $31-50$ & $50-69$ \\
\hline $\begin{array}{l}\text { Grade III (non- } \\
\text { serviceable) }\end{array}$ & $51-90$ & $5-49$ \\
\hline Grade IV (poor) & $91-$ max & $1-4$ \\
\hline Grade V (none) & not testable & 0 \\
\hline
\end{tabular}

Table 2: House-Brackmann facial nerve grading system

\begin{tabular}{|c|c|}
\hline $\begin{array}{l}\text { Grade } \\
\text { I }\end{array}$ & Normal facial function in all areas \\
\hline $\begin{array}{l}\text { Grade } \\
\text { II }\end{array}$ & $\begin{array}{l}\text { Slight Dysfunction } \\
\text { Gross: slight weakness noticeable on close inspection; } \\
\text { may have very slight synkinesis } \\
\text { At rest: normal symmetry and tone } \\
\text { Motion: forehead - moderate to good function; eye - } \\
\text { complete closure with minimum effort; mouth - slight } \\
\text { asymmetry. }\end{array}$ \\
\hline $\begin{array}{l}\text { Grade } \\
\text { III }\end{array}$ & $\begin{array}{l}\text { Moderate Dysfunction } \\
\text { Gross: obvious but not disfiguring difference between } \\
\text { two sides; noticeable but not severe synkinesis, } \\
\text { contracture, and/or hemi-facial spasm. } \\
\text { At rest: normal symmetry and tone } \\
\text { Motion: forehead - slight to moderate movement; eye - } \\
\text { complete closure with effort; mouth - slightly weak with } \\
\text { maximum effort }\end{array}$ \\
\hline $\begin{array}{l}\text { Grade } \\
\text { IV }\end{array}$ & $\begin{array}{l}\text { Moderate Severe Dysfunction } \\
\text { Gross: obvious weakness and/or disfiguring asymmetry } \\
\text { At rest: normal symmetry and tone } \\
\text { Motion: forehead - none; eye - incomplete closure; } \\
\text { mouth - asymmetric with maximum effort. }\end{array}$ \\
\hline $\begin{array}{l}\text { Grade } \\
\text { V }\end{array}$ & $\begin{array}{l}\text { Severe Dysfunction } \\
\text { Gross: only barely perceptible motion } \\
\text { At rest: asymmetry } \\
\text { Motion: forehead - none; eye - incomplete closure; } \\
\text { mouth - slight movement }\end{array}$ \\
\hline $\begin{array}{l}\text { Grade } \\
\text { VI }\end{array}$ & $\begin{array}{l}\text { Total Paralysis } \\
\text { No movement }\end{array}$ \\
\hline
\end{tabular}

Table 3: Koos grading scale

\begin{tabular}{|l|l|}
\hline Grade 1 & Tumors involve only the internal auditory canal. \\
\hline
\end{tabular}

\begin{tabular}{|l|l|}
\hline Grade 2 & Tumors extend into the cerebellopontine angle, but do \\
\hline
\end{tabular} 


\begin{tabular}{l|l}
\hline & \multicolumn{2}{|l}{ not encroach on the brainstem } \\
\hline Grade 3 & Tumor fills the entire cerebellopontine angle. \\
\hline Grade 4 & $\begin{array}{l}\text { Tumor displaces the brainstem and adjacent } \\
\text { nerves. }\end{array}$ \\
\hline Table 4. Patients demographics and clinical \\
characteristics \\
\hline \multicolumn{2}{|c}{$\mathrm{n}=30$} \\
\hline Age (year) & $47,1 \pm 12,5$ \\
Gender & \\
Male & $14(\% 46,7)$ \\
Female & $16(\% 53,3)$ \\
Duration of symptoms (month) & $4,5(0,25-120)$ \\
Comorbid disease & $6(\% 20,0)$ \\
Comorbid malignite & $3(\% 10,0)$ \\
Prior surgery & $3(\% 10,0)$ \\
Koos classification & \\
I & $5(\% 16,7)$ \\
II & $18(\% 60,0)$ \\
III & $1(\% 3,3)$ \\
IV & $6(\% 20,0)$ \\
On alternate days treatment & $10(\% 33,3)$ \\
Tumor Laterality & \\
Right & $19(\% 63,3)$ \\
Left & $11(\% 36,7)$ \\
Follow up (month) & $20(2-57)$ \\
\hline & \\
\hline
\end{tabular}

\section{DISCUSSION}

During the median 20 mo follow up, 100\% radiologic local control was achieved with statistically significant deterioration of GB and HB scores which could be attributed to treatment related toxicity.

Retrospective evaluation of vestibuler schwannoma patients treated with a dose of median 13 Gy gama-knife SRC reported a favorable local control of $97 \%$ in long term follow-up ${ }^{9,10}$. Conventional doses between 46.8-59 Gy (1.8 Gy/frx) showed similar results $^{11,12}$. Moreover, Combs et al compared the results of 200 patients treated either with SRS or conventional doses of FSRT and found no statistically significant difference between groups in terms of local control ${ }^{13}$. In a prospective evaluation of $158 \mathrm{VS}$ patients treated with $\mathrm{FSRT}^{14}$. Patients were treatedwith received a dose of $50.4 \mathrm{~Gy}$ and a safety margin of 1-2 mm was used. The local tumor control

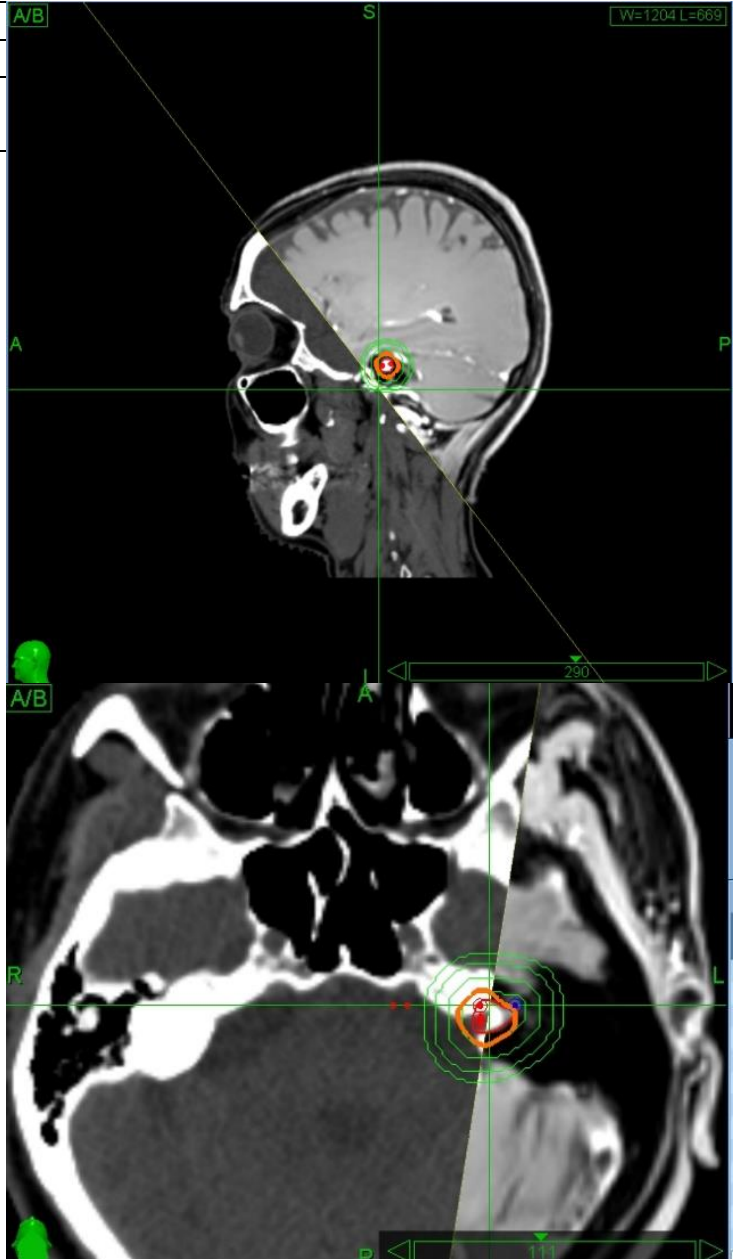

Figure 1. Fused images of a patient treated in 3 fractions

rate was $95.2 \%$ at $>7$-year of follow-up. Overall 4 patients progressed, two assessed with MRI and remaining 2 had clinical detoriation.

Toxicity related to $7^{\text {th }}$ and $8^{\text {th }}$ cranial nerves and cochlea is as important as local control. Patients with VS mostly have unilateral hearing loss as at the time of admission. In the current study, while one patient with initial hearing loss progressed to serviceable hearing after RT, 4 other patients worsened clinically after treatment so that hearing impairment rate was found to be $21 \%$ at 21 months follow up. Although pre and post RT change in GR scale was found to be statistically significant this change was not correlated with PTV, Koos Grading and maximal tumor diameter. Baschnagel et al reported that 40 patients with pretreatment serviceable hearing retained hearing $93 \%$ in the $1^{\text {st }}$ year, $77 \%$ and $73 \%$ in $2^{\text {nd }}$ and $3^{\text {rd }}$ years respectively ${ }^{15}$. They also observed that hearing impairment was seen more with SRS compared 
to FSRT but for doses below $13 \mathrm{~Gy}$, toxicity rates are same. The threshold between cochlear dose and hearing dysfunction is not clearly identified but in some SRS studies doses over 4 Gy have been associated with hearing loss ${ }^{16}$. We also found no statistically significant correlation between cochlear dosimetry and GR scale alteration. Since toxicity related hearing impairment become evident after 3 years, longer follow up is mandatory.

Due to close proximity, facial nerve is frequently jeopardized. Motor dysfunction is frequent but loss of taste may also become evident. In the study of Combs, fascial toxicity was reported for $4 \%$ of 200 patients but it was $17 \%$ and $2 \%$ for different modalities respectively. We evaluated facial nerve function with pre and post $\mathrm{HB}$ scores and found a deterioration which was statistically significant but not correlated with PTV, Coos classification and maximal tumor diameter.

In current study the trigeminal toxicity rate was 6\%.In older SRC studies, trigeminal toxicity rates reach to $60 \%(15-60 \%)^{17-19}$. The high rates of toxicities have led to a reduction in prescribing doses and in this way a reduction observed in toxicity rates. In 2000 studies, doses prescribed were reduced to 13 Gy and trigeminal nerve protection rates were higher than $95 \%^{13,20,21}$. The trigeminal toxicity rate observed in this study seems to be higher than current studies. One of the patients had VS surgery before RT but others had no known prescribed risk factor. Although there are studies showed that the presence of comorbid disease increasing the risk of developing trigeminal toxicity we could not show a statistically significant association in our series.

\section{CONCLUSION}

Due to the lack of randomize controlled study about this subject and the variability of the parameters of these studies, it is difficult to draw definitive results but SRT with CyberKnife seems appropiate for VS treatmentin terms of local control and toxicity.

Conflict of interest: The authors declare that they have no conflict of interest

\section{REFERENCES}

1. Tos M, Stangerup SE, Cayé-Thomasen $\mathrm{P}, \mathrm{Tos}$ $\mathrm{T}$, Thomsen J: What is the real incidence of vestibular schwannoma? Arch Otolaryngol Head Neck Surg 130:216-220, 2004

2. Stangerup SE, Cayé-Thomasen P. Epidemiology and natural history of vestibular schwannomas. Otolaryngologic Clinics of North America 2012;45(2):257-68.

3. Chaimoff M, Nageris BI, Sulkes J, Spitzer T, Kalmanowitz M: Sudden hearing loss as a presenting symptom of acoustic neuroma. Am J Otolaryngol 20:157-160, 1999

4. Hansasuta A, Choi CYH, Gibbs IC, Soltys SG, Tse VCK, Lieberson RE, et al. Multisession stereotactic radiosurgery for vestibular schwannomas: singleinstitution experience with 383 cases. Neurosurgery 2011;69(6):1200-9).

5. Varughese JK, Breivik CN, Tore WL, Morten LJ. Growth of untreated vestibular schwannoma: a prospective study. Journal of Neurosurgery 2012;116(4):706-12.

6. Dario Muzevic, Jelena Legcevic, Bruno Splavski, Per Cayé-Thomasen. Stereotactic radiotherapy for vestibular schwannoma. Cochrane Database of Systematic Reviews 2014, Issue 12.

7. Leksell L: A note on the treatment of acoustic tumours. Acta Chir Scand 137:763-765, 1971)

8. House, J.W., Brackmann, D.E. Facial nerve grading system. Otolaryngol. Head Neck Surg, [93] 146147. 1985

9. Boari N, Bailo M, Gagliardi F, Franzin A, Gemma M, del Vecchio A et al. Gamma Knife radiosurgery for vestibular schwannoma: clinical results at longterm follow-up in a series of 379 patients. J Neurosurg. 2014 Dec;121 Suppl:123-42

10. Lunsford LD, Niranjan A, Flickinger JC, Maitz A, Kondziolka D. Radiosurgery of vestibular schwannomas: summary of experience in 829 cases. J Neurosurg. 2013 Dec;119 Suppl:195-9.

11. McClelland S, Gerbi BJ, Higgins PD, Orner JB, Hall WA. Safety and efficacy of fractionated stereotactic radiotherapy for acoustic neuromas. J Neurooncol. 2008 Jan;86(2):191-4. Epub 2007

12. Andrews DW, Werner-Wasik M, Den RB, Paek SH, Downes-Phillips B, Willcox TO et al. Toward Dose Optımızation For Fractionated Stereotactic Radiotherapy For Acoustic Neuromas: Comparison Of Two Dose Cohorts. Int J Radiat Oncol Biol Phys. 2009 Jun 1;74(2):419-26

13. Combs SE, Kano T, Schulz-Ertner D, Huber PE, Debus R. Differences In Clinical Results After Linac-Based Single-Dose Radiosurgery Versus Fractionated Stereotactic Radiotherapy For Patients With Vestibular Schwannomas. Int. J. Radiation Oncology Biol. Phys., Vol. 76, No. 1, pp. 193-200, 2010

14. Litre F, Rousseaux P,Jovenin N, Bazin A, Peruzzi P, Wdowczyk D et al. Fractionated stereotactic radiotherapy for acoustic neuromas: A prospective monocenter study of about 158 cases. Radiotherapy and Oncology 106 169-174,2013

15. Baschnagel AM, Chen PY, Bojrab D, Pieper D, Kartush J, Didyuk O et al. Hearing preservation in 
patients with vestibular schwannoma treated with Gamma Knife surgery. J Neurosurg. 2013 Mar;118(3):571-8.

16. Benghiat $H$, Heyes $G$, Nightingale $P$, Hartley A, Tiffany M, Spooner D et al. Linear Accelerator Stereotactic Radiosurgery for Vestibular Schwannomas: A UK Series. Clinical Oncology xxx (2014) 1-7

17. Foote RL, Coffey RJ, Swanson JW, Harner SG, Beatty CW, Kline RW, et al. Stereotactic radiosurgery using the gamma knife for acoustic neuromas. Int $\mathbf{J}$ Radiat Oncol Biol Phys 1995;32:1153-1160.

18. Suh JH, Barnett GH, Sohn JW, Kupelian PA, Cohen $\mathrm{BH}$. Results of linear accelerator-based stereotactic radiosurgery for recurrent and newly diagnosed acoustic neuromas. Int J Cancer 2000;90: 145-151.

19. Flickinger JC, Lunsford LD, Linskey ME, Duma CMş Kondziolka D. Gamma knife radiosurgery for acoustic tumors: Multivariate analysis of four year results. Radiother Oncol 1993;27:91-98.

20. Myrseth E, Møller P, Pedersen PH, Vassbotn FS, Wentzel-Larsen T, Lund-Johansen M. Vestibular schwannomas: clinical results and quality of life after microsurgery or gamma knife radiosurgery. Neurosurgery 56:927-935; discussion 927-935, 2005.

21. Fukuoka S, Takanashi M, Hojyo A, Konishi M, Tanaka C, Nakamura H. Gamma knife radiosurgery for vestibular schwannomas. Prog Neurol Surg 2009; 22:45-62. 